\title{
Macroelements and heavy metals content in energy crops cultivated on contaminated soil under different fertilization-case studies on autumn harvest
}

\author{
Marta Pogrzeba $^{1} \cdot$ Szymon Rusinowski ${ }^{1}$ · Jacek Krzyżak ${ }^{1}$
}

Received: 14 July 2017 / Accepted: 5 February 2018 / Published online: 16 February 2018

(C) The Author(s) 2018. This article is an open access publication

\begin{abstract}
Heavy metals (HMs) contamination of soils is a major problem occurring worldwide. Utility of energy crops for biofuel feedstock production systems offers a feasible solution for a commercial exploitation of an arable land contaminated with HMs. Experiments involved field testing of Miscanthus $\mathrm{x}$ giganteus and Spartina pectinata cultivated on HMs-contaminated soil with standard NPK fertilizers and commercially available microbial inoculum. Biomass yield, water content, macronutrients (N, P, K, $\mathrm{Mg}, \mathrm{Ca})$, and heavy metal $(\mathrm{Cd}, \mathrm{Pb}, \mathrm{Zn})$ concentrations in plant shoots were assessed at the end of the first and the second growing season. Independently of the applied fertilizers, Miscanthus x giganteus produced higher biomass yield while contrary results were obtained for S. pectinata. Higher HMs content in plants influenced the status of the mineral macronutrients in particular $\mathrm{N}$ and $\mathrm{K}$. Occurrence of hasted senescence induced by drought in the second growing season caused reduction in the concentrations of all elements (except $\mathrm{Pb}$ ), due to earlier rhizomes relocation.
\end{abstract}

Keywords Miscanthus x giganteus $\cdot$ Spartina pectinata $\cdot$ Heavy metals $\cdot$ Macronutrients $\cdot$ Senescence $\cdot$ Drought

\section{Introduction}

There are approximately 20 elements essential for plant growth and development. They can be divided into two groups: mineral macro- and micronutrients. Mineral macronutrients are required for plants in relatively high amounts in comparison with other elements. Mineral macronutrients (N, P, K, Ca, Mg, Fe, S) are divided into primary and secondary categories (Tripathi et al. 2014). Primary macronutrients represented by N, P, and $\mathrm{K}$ are often main components of fertilizers which are introduced to soil in different chemical forms. Both groups of macronutrients play a significant role in the metabolism of plants (protein,

Responsible editor: Hailong Wang

Electronic supplementary material The online version of this article (https://doi.org/10.1007/s11356-018-1490-8) contains supplementary material, which is available to authorized users.

Marta Pogrzeba

m.pogrzeba@ietu.pl

1 Institute for Ecology of Industrial Areas, 6 Kossutha Street, 40-844 Katowice, Poland
DNA, RNA, plant photosynthetic pigment components, enzyme cofactors associated with metabolites transport) as well as in protecting them against different abiotic stressors, including the presence of heavy metals (HMs) in the environment (Tripathi et al. 2014; Waraich et al. 2011; Nazar et al. 2012).

Heavy metals in the environment are a common plant stress factor, which can be harmful to plants as well as indirectly to humans due to their placement in the trophic chain, since plants accumulate them (Alloway 2013). Some HMs are however necessary for the development of plants, e.g., $\mathrm{Fe}, \mathrm{Cu}, \mathrm{Mn}$, $\mathrm{Mo}$, and $\mathrm{Zn}$, although their presence in excess amounts can be toxic for plants. Beyond that, there are also other HMs $(\mathrm{Cd}$, $\mathrm{Hg}, \mathrm{Pb}$ ) which are not associated with plant development and can cause damage to them (Siedlecka 2014).

The presence of HMs in the environment can have a natural (e.g., volcanic emission) and/or industrial (e.g., smelters, coal mines) origin. Industry is the main emitter of HMs to the environment, especially in regions associated with the processing of these metals. Such areas are usually highly contaminated, where the pollutants can also spread throughout the vicinity (e.g., due to dust emission) consequently influencing cultivated crops. Therefore, such arable lands should be excluded from agricultural production (Van Slycken et al. 2013). 
Biomass production using perennial plants with low cultivation requirements could be an alternative here. Application of such approach provides a double benefit, both in degraded land management as well as phytoremediation, due to the stabilization or extraction of toxic elements by plants (Meers et al. 2010; Balsamo et al. 2015).

Miscanthus $\mathrm{x}$ giganteus and Spartina pectinata are secondgeneration energy crops which are perennial grasses capable of performing $\mathrm{C}_{4}$ photosynthesis. It makes them much more effective in biomass production than $\mathrm{C}_{3}$ plants. Due to the specific development of their underground organs, both grasses are able to allocate nutrients to rhizomes during senescence (Sarath et al. 2014). Mineral composition of these plant species is very important when considering the biomass feedstock destination. Additionally, it has also been found, that $M$. x giganteus (Pogrzeba et al. 2010; Korzeniowska and Stanislawska-Glubiak 2015; Pogrzeba et al. 2017) and S. pectinata (Zhang et al. 2015; Korzeniowska and Stanislawska-Glubiak 2015) demonstrate the ability to accumulate HMs in the aboveground organs. This capability combined with a high biomass yield make these plants particularly useful for cultivation on HMs contaminated lands (Van Ginneken et al. 2007).

There are numerous literature sources addressing the relationship between HMs and mineral macro- and micronutrients. They however usually correspond to annual plants cultivated for food and medical purposes (Singh et al. 1990; Zhang et al. 2002, Bello et al. 2004; Khan and Bano 2016). Additionally, there is a lack of papers considering the effect of heavy metals on mineral nutrient status, that would refer to field tested perennial grasses cultivated for biomass feedstock on contaminated arable land (Nsanganwimana et al. 2016).

The aim of the presented study was to describe the relationship between HMs and mineral macronutrients uptake to the aboveground plant organs of $M$. x giganteus and $S$. pectinata cultivated in field conditions on a contaminated arable land, the changes in mineral composition of plants during their acclimatization (first two growing seasons from trial establishment), and the influence of NPK fertilizer and commercially available microbial inoculum on the plant mineral composition. Thus, we hypothesize that changing in plant mineral composition depends on the differences in HMs concentration in plant shoots caused by fertilization rather than on applied fertilizers itself.

\section{Materials and methods}

\section{Site description}

The presented data was collected at the end of the first and second growing season (September 2014 and 2015) from a HM-contaminated arable area in Bytom (Upper Silesia,
Poland, 50 20' 43.0" N $18^{\circ} 57^{\prime} 19.6^{\prime \prime}$ E) on an experimental site of the Institute for Ecology of Industrial Areas. This agricultural land was affected in the last century by dust falling from lead and zinc smelter, causing HMs soil contamination, especially zinc, cadmium, and lead. The soil concentrations of $\mathrm{Pb}, \mathrm{Cd}$, and $\mathrm{Zn}$ at the site exceed the limits set by Polish law (Dz.U. 2016 poz. 1395), which refers to the exclusion of such areas from food production. The climate in Poland is moderate. Average values of temperature and total precipitation measured during 2014 and 2015 growing season were $17 / 17^{\circ} \mathrm{C}$ and $455 /$ $300 \mathrm{~mm}$, respectively (Institute of Meteorology and Water Management, Fig. 1).

\section{Experimental design}

The trial of $M$. x giganteus (M) and $S$. pectinata (S) was established in May 2014. For M. x giganteus, 45-g rhizomes were planted at $10-\mathrm{cm}$ depths, obtained from direct cutting of rhizomes (7-10-cm length) at the beginning of the May 2014. For $S$. pectinata, root seedlings were precultivated in greenhouse conditions. All planting materials were obtained from uncontaminated sites. On each plot, 49 plants were planted over an area of $16 \mathrm{~m}^{2}$ (3 plants per $1 \mathrm{~m}^{2}$ ) with a buffer zone of $4 \mathrm{~m}$ between each plot, which protected plants against uncontrolled fertilization. Single plot trials with pseudo-replication were used due to apprehension of uncontrolled widespread of microbial inoculum during foliar application.

Each plot was treated in a different way:

- Control (without treatment);

- NPK standard fertilization-applied directly to the soil before planting (M. x giganteus - nitrogen $70 \mathrm{~kg} \mathrm{ha}^{-1}$, phosphorus $30 \mathrm{~kg} \mathrm{ha}^{-1}$ as $\mathrm{P}_{2} \mathrm{O}_{5}$, and potassium $45 \mathrm{~kg} \mathrm{ha}^{-1}$ as $\mathrm{K}_{2} \mathrm{O} ; \mathrm{S}$. pectinata - nitrogen $80 \mathrm{~kg} \mathrm{ha}^{-1}$, phosphorus $50 \mathrm{~kg} \mathrm{ha}^{-1}$ as $\mathrm{P}_{2} \mathrm{O}_{5}$, and potassium $75 \mathrm{~kg} \mathrm{ha}^{-1}$ as $\mathrm{K}_{2} \mathrm{O}$ ), using commercially available fertilizers; Polifoska (Grupa Azoty, Zakłady Chemiczne "Police" S.A., Poland: N$4 \%$ as $\mathrm{NH}_{4} ; \mathrm{P}_{2} \mathrm{O}_{5}-22 \% ; \mathrm{K}_{2} \mathrm{O}-32 \% ; \mathrm{MgO}-2 \%$; $\mathrm{SO}_{3}-9 \%$ ) and ammonium nitrate (PULAN® $34 \mathrm{~N}$, Grupa Azoty Zakłady Azotowe "Puławy" S.A., Poland: $\mathrm{NH}_{4}-17 \% ; \mathrm{NO}_{3}-17 \%$ )

- Commercial microbial inoculum-Emfarma Plus® ProBiotics Poland (lactic acid bacteria $>3.0 \times 10^{5} \mathrm{cfu} \mathrm{ml}^{-1}$, yeast $<1.0 \times 10^{6} \mathrm{cfu} \mathrm{ml}^{-1}$, and purple non-sulfur bacteria $>1.0 \times 10^{4} \mathrm{cfu} \mathrm{ml}^{-1}$ in molasses suspension). Eight liters of $10 \%$ water solution of Emfarma Plus ${ }^{\circledR}$ was sprayed on the soil surface; additionally, the roots of the seedlings were soaked in this solution at the beginning of the experiment. Plant leaves were treated monthly during the growing season with $10 \%$ water solution of Emfarma Plus® as aerosol treatment ( 81 per plot) 


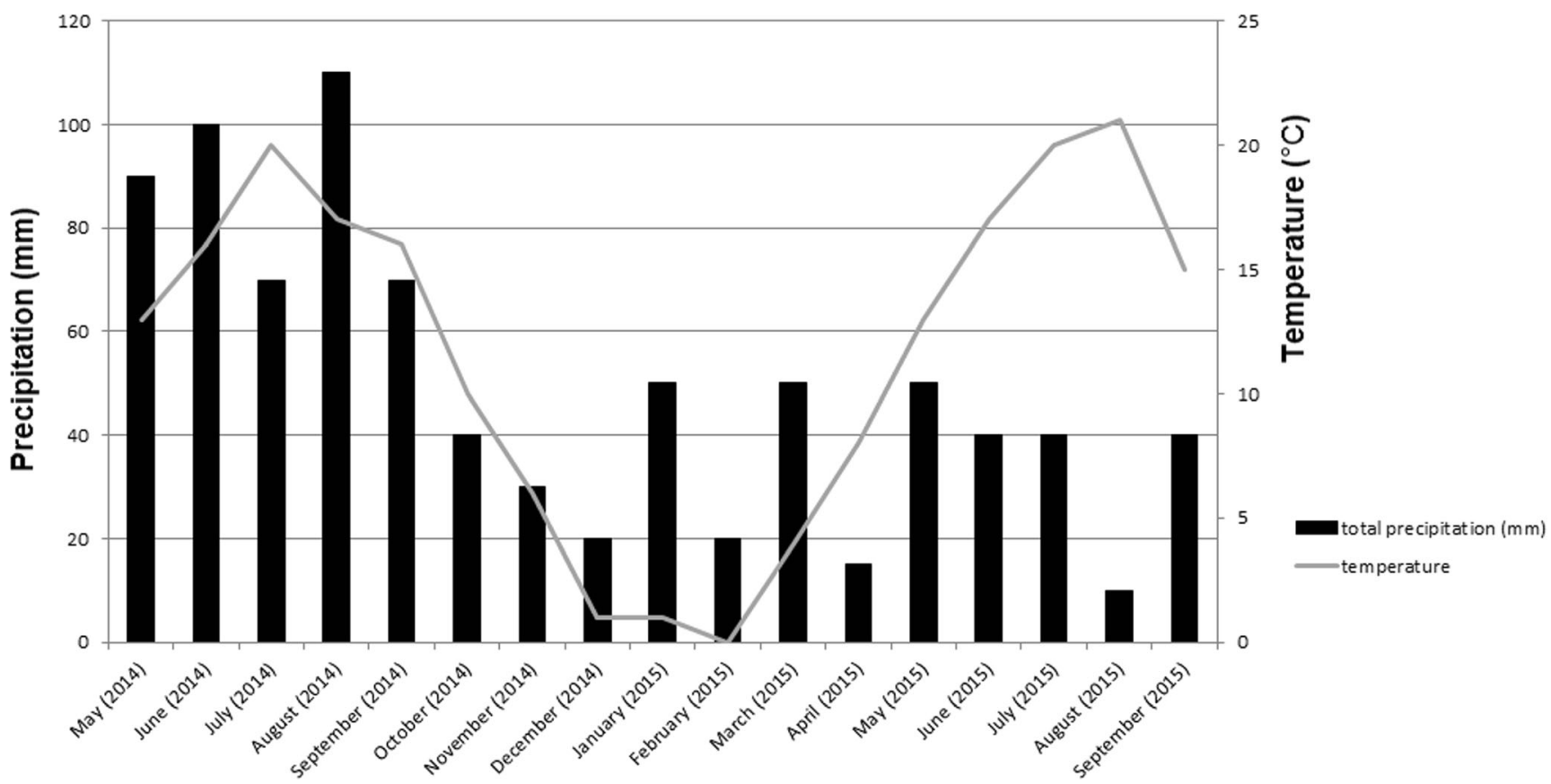

Fig. 1 Meteorological data presented monthly total precipitation (columns) and average temperature (line) from May 2014 to September 2015

\section{Plant material sampling}

The data for further analysis was collected from plots divided into three sections. Within sections (a) and (c), two plants were selected, while within section (b), one plant was selected at random. Plots were divided into sections to obtain adequate sample randomization. For each of the randomly selected plants, stems were harvested for further analysis (Fig. 2).

\section{Soil characteristic and biomass elemental analysis}

Soil $\mathrm{pH}$ was measured in $\mathrm{H}_{2} \mathrm{O}$ (ratio 1:2.5 $\mathrm{m} / \mathrm{v}$ ) with a combination of glass/calomel electrode (OSH 10-10, METRON, Poland) and a pH-meter (CPC-551, Elmetron, Poland) at $20{ }^{\circ} \mathrm{C}$. The electrical conductivity was determined by an

\begin{tabular}{|c|c|c|c|c|c|c|}
\hline$E F$ & $E F$ & $E F$ & $E F$ & $E F$ & $E F$ & $E F$ \\
\hline$E F$ & $a$ & $a$ & $a$ & $a$ & $a$ & $E F$ \\
\hline$E F$ & $a$ & $a$ & $a$ & $a$ & $a$ & $E F$ \\
\hline$E F$ & $b$ & $b$ & $b$ & $b$ & $b$ & $E F$ \\
\hline$E F$ & $c$ & $c$ & $c$ & $c$ & $c$ & $E F$ \\
\hline$E F$ & $c$ & $c$ & $c$ & $c$ & $c$ & $E F$ \\
\hline$E F$ & $E F$ & $E F$ & $E F$ & $E F$ & $E F$ & $E F$ \\
\hline
\end{tabular}

Fig. 2 Scheme of plots division in the experiment. EF — plants exposed to edge effect. $a, b, c-$ section where samples were collected
ESP 2ZM electrode (EUROSENSOR, Poland) according to the Polish norm PN-ISO 11265:1997.

Soil texture was evaluated by the hydrometric method according to the Polish norm PNR-04032:1998.

Soil organic matter content $(\mathrm{OM})$ was measured by loss on ignition as follows: air dry soil was dried at $105^{\circ} \mathrm{C}$ for $24 \mathrm{~h}$ and then $(5 \mathrm{~g})$ treated with $550{ }^{\circ} \mathrm{C}$ for $4 \mathrm{~h}$ (Pogrzeba et al. 2017). Soil organic carbon $\left(\mathrm{C}_{\text {org }}\right)$ was assessed according to PN-ISO 14235:2003, sulfur content was assessed according to PN-EN 14582:2017.

The total content of metals in the soil and plant tissues was obtained using hot plate digestion $\left(\mathrm{HNO}_{3}\right.$ and $\mathrm{HClO}_{3}$, at ratio of 4:1) and flame atomic absorption spectrometry (SpektrAA 300, Varian INC., USA). Soil samples were digested in aqua regia according to the ISO 11466:1995, while plant samples were digested in nitric and perchloric acid (4:1 v/v) (Schierup and Larsen 1981). Total nitrogen concentration in soil was measured using dry combustion method according to norm ISO 13878:1998. Available phosphorus and available potassium concentrations were assessed according to the method described by Egner et al. (1960). Total nitrogen concentration $(\mathrm{N})$ in plant leaves was measured using the titration method (Bremner 1996), whereas total phosphorus (P) and potassium (K) concentration in plant leaves was assessed in the previously mineralized samples using ICP (Liberty 220, Varian, USA).

\section{Biomass production}

Total biomass production was assessed at the end of each growing season. The collected plant material was dried at 
$70{ }^{\circ} \mathrm{C}$, weighed, and the biomass yield of dry weight per square meter was calculated.

\section{Plant visual observation}

Photographic documentation was collected once per month during each of the growing seasons. For this paper, September photos were described as most valuable for data analysis due to visible differences in plant development between the first and the second growing season.

\section{Statistical analyses}

Data was analyzed using a three-way ANOVA, followed by a post hoc comparison using the Fisher LSD test $(P<0.05)$. Principal component analysis (PCA) was performed on a correlation matrix to detect any relationship between accumulation of analyzed elements and water content. Additionally, PCA was used to distinguish cases clusters created on two principal component (PC) axes. All data statistical analyses were performed using Statistica 10 (Statsoft, USA). Spider charts where constructed using Excel MS Office (Microsoft, USA), and standardization of data used for charts construction were performed using the Statistica 10 Software (Statsoft, USA).

\section{Results}

\section{Soil characteristic}

Soil physicochemical characteristics are presented in Table 1.

Each of the analyzed parameters in the initial soil samples was slightly lower for $S$. pectinata plots when compared with $M$. x giganteus plots. Heterogenic distribution of elements could be caused by irregular dust fall emitted by the smelter and unequal distribution of agricultural treatments in the past. No statistically significant differences were found for the analyzed soil parameters among $S$. pectinata plots, with the exception of $\mathrm{C}_{\mathrm{ORG}}$ for plot $\mathrm{S}-\mathrm{C}$. Contrary to $\mathrm{C}_{\mathrm{ORG}}$, $\mathrm{Mg}$ content was different for each of the $M$. x giganteus plots. It was found that $\mathrm{Mg}$ concentration at the M-NPK plot was higher by $15 \%$ although the highest value was measured at $81 \%$ for the MINC plot in comparison to the control. It can be assumed that among species, soil parameters were highly homogenous.

\section{Heavy metals and mineral macronutrients plant concentrations (spider charts and PCA)}

Spider charts (Fig. 3a, b) are an easy way to visualize patterns in feature characteristics of plant organisms. The presented spider charts can be divided in to three sections: heavy metal $(\mathrm{Zn}, \mathrm{Cd}, \mathrm{Pb})$ accumulation, primary mineral macronutrients
$(\mathrm{N}, \mathrm{K}, \mathrm{P})$, and secondary mineral macronutrients $(\mathrm{Mg}, \mathrm{Ca})$ with water content. For both cultivated species, overall decrease in all parameters (except $\mathrm{Pb}$ ) was visible after the second growing season, in comparison to the first one.

Principal component analysis (Fig. 4a, b) shows the multivariate relationships between the plants' ability to accumulate HMs, primary mineral macronutrients, secondary mineral macronutrients, and, additionally, plant water content. The analyzed cases (Fig. 4a) were divided by PC1 and PC2 axis into four groups, which corresponded to the species and the growing seasons $(M$. x giganteus growing season 2014, M. x giganteus growing season 2015, S. pectinata growing season 2014, $S$. pectinata growing season 2015). The distance between the clusters indicates the differences in the analyzed parameters within the groups. The distance between $M$. x giganteus and $S$. pectinata after the first growing season is larger than after the second. The differences in the distances within the tested species after the first and second growing season are similar. PCA showed that the treatments are not differentiated into subgroups within the growing season and the tested plant species. Variables (Fig. 4b) can be divided into three groups of parameters: primary macronutrients with water content (1), HMs (except $\mathrm{Pb}$ ) with secondary mineral macronutrients (2), and $\mathrm{Pb}$ (3). The first and second groups are mainly conditioned by $\mathrm{PC} 1$, whereas the third group $(\mathrm{Pb})$ is mainly conditioned by $\mathrm{PC} 2$. However, $\mathrm{Mg}$ and $\mathrm{Cd}$ are conditioned by $\mathrm{PC} 1$, demonstrating that those parameters have also a high affinity to PC2. Due to distribution of variables, it was found that the increase of $\mathrm{Pb}$ is the main conditioning factor of the second growing season with a simultaneously reduced amount of other elements in the aboveground plant organs, which corresponds to the results visible on the spider charts.

Among $M$. x giganteus samples supplemented by fertilizers in the growing season 2014, the highest HMs accumulation was observed for plants treated with NPK while the lowest accumulation ability was in $M$. x giganteus untreated and treated with an inoculum. For $S$. pectinata in the growing season 2014, the highest heavy metals (mostly $\mathrm{Zn}$ ) accumulation was observed for plants treated with the inoculum; however, in the case of NPK treated and control plants, the same or lower values were observed compared to the inoculated plants. In $M$. x giganteus samples collected at the end of the first growing season, the highest primary mineral macronutrients content was observed for plants treated with the inoculum, whereas significantly lower values (except $\mathrm{N}$ in control plants, which was statistically the same) were observed for untreated and NPK-treated plants. The lowest results for N and $\mathrm{K}$ were found in plants treated with NPK fertilizer. Among S. pectinata plants in the growing season 2014, the highest accumulation of primary macronutrients was observed 


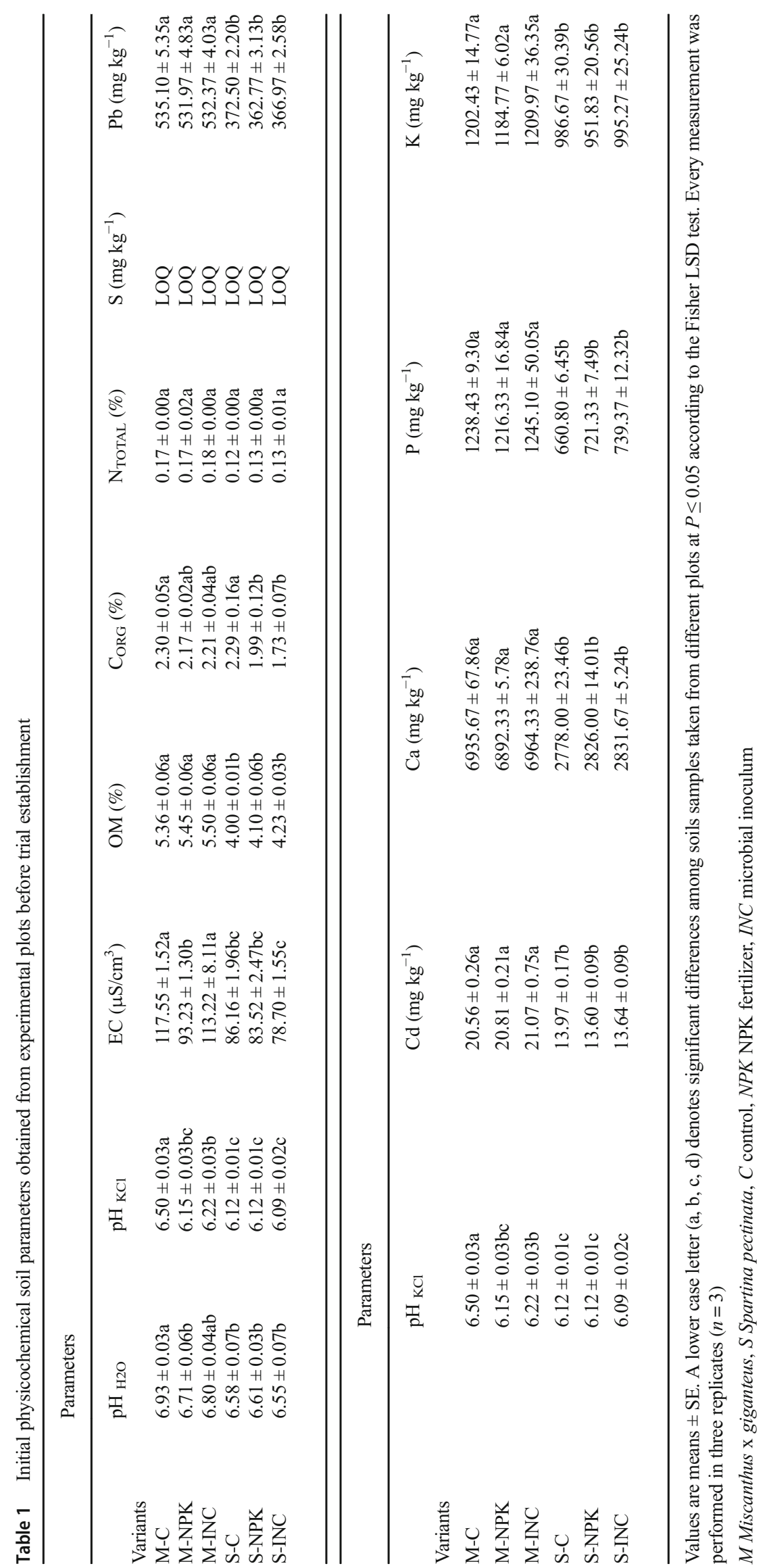


a

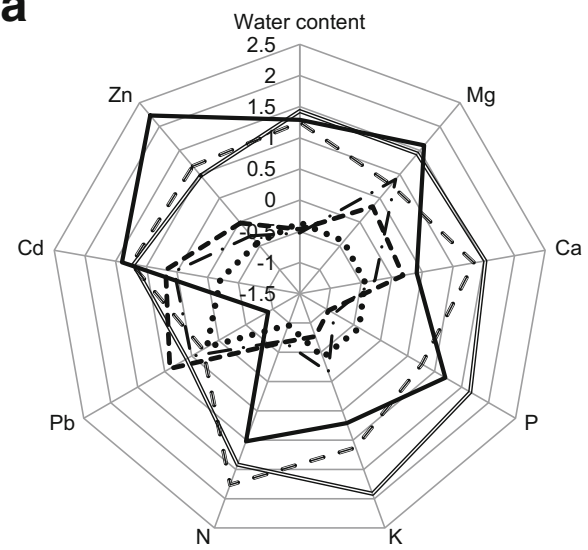

b

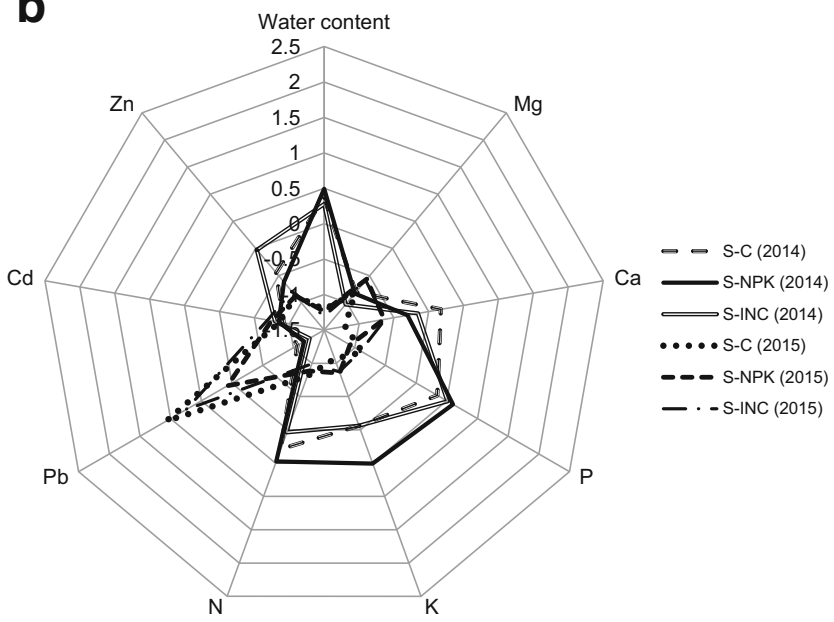

Fig. 3 Spider charts constructed on macronutrients, heavy metals, and water content show patterns indicated changes of those parameters; among treatment ( $C$ control, NPK NPK fertilizer treated plant, $I N C$ microbial inoculum treated plant) and growing season (14-growing season 2014, 15-growing season 2015) for: a Miscanthus x giganteus (M) and b Spartina pectinata (S). Mg, Ca, P, K, N, Pb, Cd, Zn - elements accumulation in aboveground plants organs. For better data visualization, all presented values were standardized. Every measurement was performed in 5 replicate $(n=5)$

for plants treated with NPK fertilizer. Moreover, equally lower values of these elements were found for $S$. pectinata control plants and those treated with microbial inoculum in comparison with an NPK treatment.

For $M$. x giganteus plants in the growing season 2014, Mg accumulation was the highest for all plants treated with NPK and microbial inoculum, with statistical significant difference to the control. Accumulation of $\mathrm{Ca}$ in the growing season 2014 was the same for M. x giganteus treated with an inoculum and the control. Moreover, NPK treatment caused a lower $\mathrm{Ca}$ accumulation when compared to control. Accumulation of $\mathrm{Mg}$ among $S$. pectinata plants was the same for each experimental option. Different observations were found for $\mathrm{Ca}$, where S. pectinata treated with NPK and with microbial inoculum had slightly lower Ca plant concentration in comparison to the control. Water content after the first growing season was higher for $M$. x giganteus when compared to $S$. pectinata; however, in both cases, treatments had no significant influence on this parameter.

After the second growing season, trends for HMs and primary mineral macronutrients were similar to those observed in the first one. Among secondary macronutrients accumulation, $\mathrm{Mg}$ and $\mathrm{Ca}$ showed different trends in the growing season of 2015 when compared to the growing season of 2014. M. x giganteus plants cultivated with NPK and inoculum fertilizers showed higher Mg concentration in the aboveground organs when compared to the control. Among the treatments, the highest Mg concentrations were observed for inoculated $M$. x giganteus plants. In the growing season 2015, the highest $\mathrm{Ca}$ concentration was observed for NPK-treated M. x giganteus; however, lower and statistically equal values were reported for plants treated with the inoculum and the control plants. Among S. pectinata plants, tendencies in accumulation of HMs and primary macronutrients during the growing season of 2015 were the same when compared to the growing season of 2014. Element contents were the same independent of the treatment, with the only exception of $\mathrm{Pb}$, which was significantly lower in comparison to the control. Concerning the secondary mineral macronutrients, accumulation in the second growing season showed that treatments did not affect $\mathrm{Ca}$ and $\mathrm{Mg}$ accumulation. After the growing season 2015, water content showed the same trends as in the growing season 2014.

This section corresponds to an overall pattern trend of the three groups: HMs, primary macronutrients, secondary macronutrients and water content. Statistical analysis of values used for spider chart construction, specific for the described parameters is presented in Table 2. In addition to the presented analysis, three-way ANOVA was performed to detect which factors, i.e., plant, year, fertilization, drove changes in the analyzed parameters (Table 3). Undoubtedly, factors corresponding to the plant species and the year of cultivation caused meaningful differences among all the investigated parameters. Fertilization affected significantly only $\mathrm{Mg}$ and $\mathrm{Zn}$ concentration in the investigated plant biomass. While considering a combined effect of the factors, i.e., plant $\times$ year $\times$ fertilization, the significant changes appeared among $\mathrm{N}, \mathrm{Pb}$, and $\mathrm{Zn}$ concentrations in the plant biomass.

\section{Plant biomass production}

After the growing season 2014, higher biomass yield was found for $S$. pectinata in comparison to $M$. x giganteus (by about $126 \%$ ). Moreover, the treatments did not influence the yield. A visible effect was observed for treatments in M. x giganteus as well as in S. pectinata plants after the growing season 2015. It inferred that the 
Fig. 4 Principal component analysis distinguished into two parts: ordination of case along two PCA axis (PC1 x PC2) (a) and correlation between variables along two PCA axis (PC1 x PC2) (b) black and gray geometric figures representing Miscanthus x giganteus and Spartina pectinata, respectively. Open and close geometric figure representing 2014 and 2015 growing season, respectively; $\square-$ control plants; o-NPK fertilizer-treated plants; $\Delta$-microbial inoculum-treated plants; N, P, K, Zn, Ca, Cd, Mg, and $\mathrm{Pb}$ - elements concentration in aboveground plant organs; WC-water content in biomass
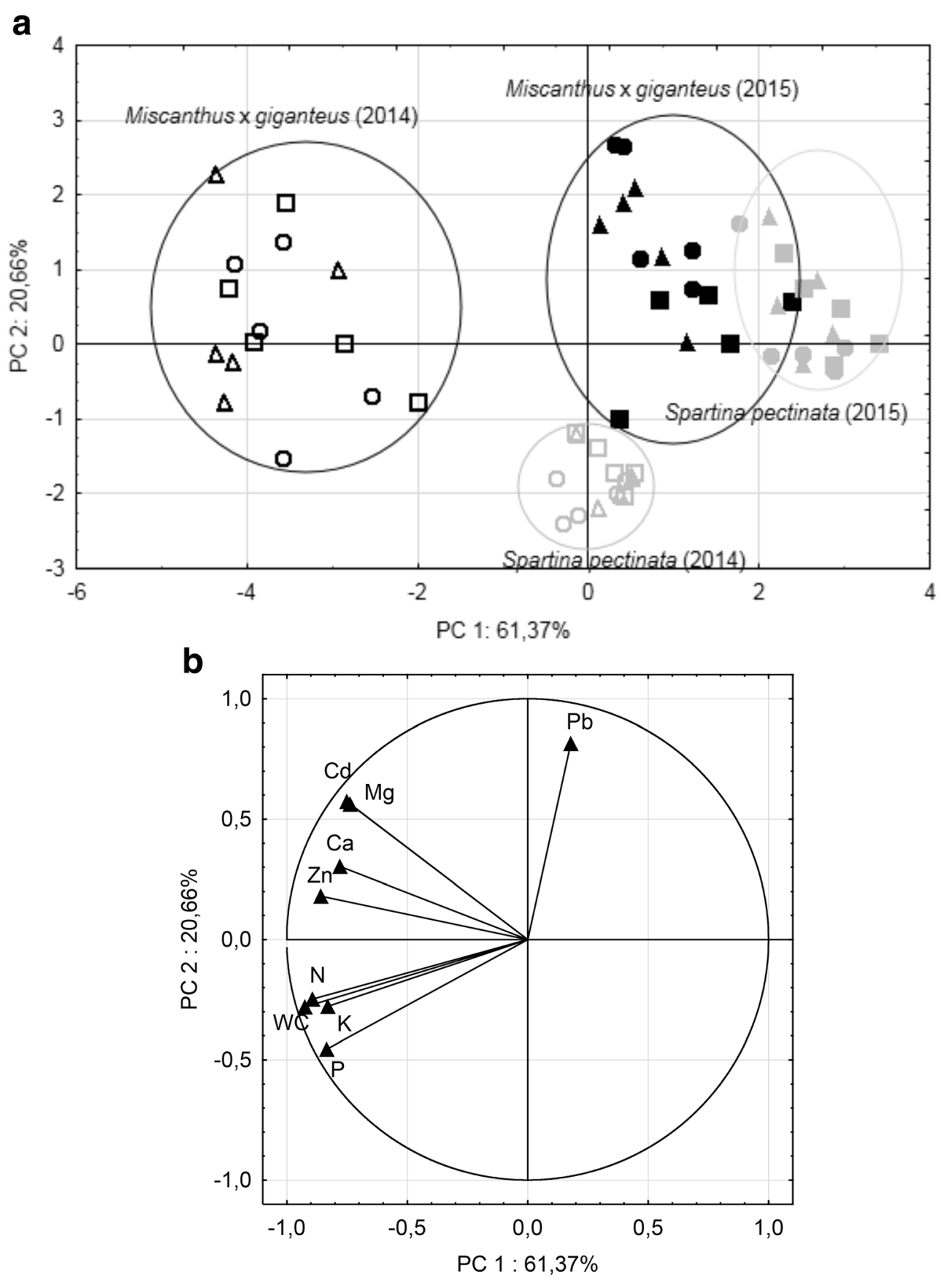

inoculum had a different impact on both species. $M$. x giganteus biomass yield was increased by $14 \%$, while $S$. pectinata biomass decreased by $26 \%$ when compared to the control. NPK treatment did not affect $S$. pectinata biomass production; however, it increased biomass yield by $18 \%$ in NPK-treated M. x giganteus (Fig. 5).

\section{Plants visual observation}

Plant photography is presented in Fig. S1. Beside visual differences in the height and stem density of individual plants for both growing seasons, there is a visible difference in the surface of the withered zones observed for $M$. x giganteus plants as well as for $S$. pectinata, which is larger at the end of the second growing season (beginning in September). Moreover, the withering effect of both species was not determined by the application of fertilizers. The results presented in the "Heavy metals and mineral macronutrients plant concentrations (spider charts and PCA)" section together with the photographic documentation corresponding to this section indicate hasted senescence in the 2015 growing season, when compared to 2014. Plant senescence occurred earlier due to drought conditions during the 2015 growing season. 
Table 2 Matrix shows statistical significant differences among analyzed parameters presented on spider charts (Fig. A.3, B.2)

\begin{tabular}{|c|c|c|c|c|c|c|c|c|c|}
\hline & Parar & eters & & & & & & & \\
\hline & WC & $\mathrm{Mg}$ & $\mathrm{Ca}$ & $\mathrm{P}$ & $\mathrm{K}$ & $\mathrm{N}$ & $\mathrm{Pb}$ & $\mathrm{Cd}$ & $\mathrm{Zn}$ \\
\hline \multicolumn{10}{|l|}{ Variants } \\
\hline $\mathrm{M}-\mathrm{C} / 14$ & $\mathrm{a}$ & $\mathrm{cd}$ & $\mathrm{a}$ & $\mathrm{bc}$ & $\mathrm{b}$ & $\mathrm{a}$ & $\mathrm{a}$ & $a b$ & $\mathrm{~b}$ \\
\hline M-NPK/14 & $\mathrm{a}$ & $\mathrm{a}$ & $\mathrm{b}$ & $a b$ & $\mathrm{~b}$ & $\mathrm{~b}$ & $\mathrm{c}$ & $\mathrm{a}$ & $\mathrm{a}$ \\
\hline M-INC/14 & $\mathrm{a}$ & $\mathrm{ab}$ & $\mathrm{a}$ & $\mathrm{a}$ & $\mathrm{a}$ & $\mathrm{a}$ & $\mathrm{a}$ & $\mathrm{ab}$ & $\mathrm{b}$ \\
\hline M-C/15 & $\mathrm{c}$ & $\mathrm{f}$ & bcd & $\mathrm{d}$ & def & $\mathrm{d}$ & $\mathrm{b}$ & $\mathrm{d}$ & cde \\
\hline M-NPK/15 & $\mathrm{c}$ & $\mathrm{e}$ & $\mathrm{bc}$ & $\mathrm{e}$ & ef & $\mathrm{d}$ & a & $\mathrm{bc}$ & $\mathrm{c}$ \\
\hline M-INC/15 & $\mathrm{c}$ & $\mathrm{d}$ & $\mathrm{bc}$ & de & ce & $\mathrm{d}$ & $a b$ & $\mathrm{c}$ & $\mathrm{cd}$ \\
\hline $\mathrm{S}-\mathrm{C} / 14$ & $\mathrm{~b}$ & ef & a & $\mathrm{c}$ & $\mathrm{cd}$ & $\mathrm{c}$ & $\mathrm{c}$ & $\mathrm{e}$ & $\mathrm{cd}$ \\
\hline S-NPK/14 & $\mathrm{b}$ & ef & $\mathrm{bc}$ & $\mathrm{c}$ & $\mathrm{bc}$ & $\mathrm{c}$ & $\mathrm{c}$ & $\mathrm{e}$ & $\mathrm{d}$ \\
\hline S-INC/14 & $\mathrm{b}$ & $\mathrm{f}$ & $\mathrm{c}$ & $\mathrm{c}$ & $\mathrm{cd}$ & $\mathrm{c}$ & $\mathrm{c}$ & $\mathrm{e}$ & $\mathrm{c}$ \\
\hline $\mathrm{S}-\mathrm{C} / 15$ & $\mathrm{~d}$ & ef & $\mathrm{d}$ & de & $\mathrm{f}$ & $\mathrm{d}$ & $\mathrm{a}$ & $\mathrm{e}$ & $\mathrm{e}$ \\
\hline S-NPK/15 & d & ef & $\mathrm{cd}$ & e & $\mathrm{f}$ & $\mathrm{d}$ & $\mathrm{b}$ & de & e \\
\hline S-INC/15 & $\mathrm{d}$ & ef & $\mathrm{cd}$ & de & $\mathrm{f}$ & $\mathrm{d}$ & $a b$ & de & d \\
\hline
\end{tabular}

A lower case letter (a, b, c, d, e, f-where " $a$ " corresponds to the highest value and "f" to the lowest) denotes significant differences among plants elements and water content taken from different plots at $P \leq 0.05$ according to Fisher LSD test. Every measurement was performed in five replicates $(n=5)$

$M$ Miscanthus x giganteus, S Spartina pectinata, $C$ control, NPK NPK fertilized plants, INC microbial inoculated plants

\section{Discussion}

It was found that $M$. $\mathrm{x}$ giganteus biomass production seems to be more efficient $\left(0.5-4.4 \mathrm{~kg} \mathrm{~m}^{-2}\right.$ d.w. $)$ when compared with S. pectinata (0.4-1.8 $\mathrm{kg} \mathrm{m}^{-2}$ d.w.) (Lewandowski et al. 2003). In the current study, after the second growing season, the obtained biomass yield was in the range of the abovementioned values for both species. However, the yield of the first year biomass was lower due to plant acclimatization (Borkowska and Molas 2013). A higher biomass yield for $S$. pectinata in the first growing season and similar for both species during the second could be attributed to higher

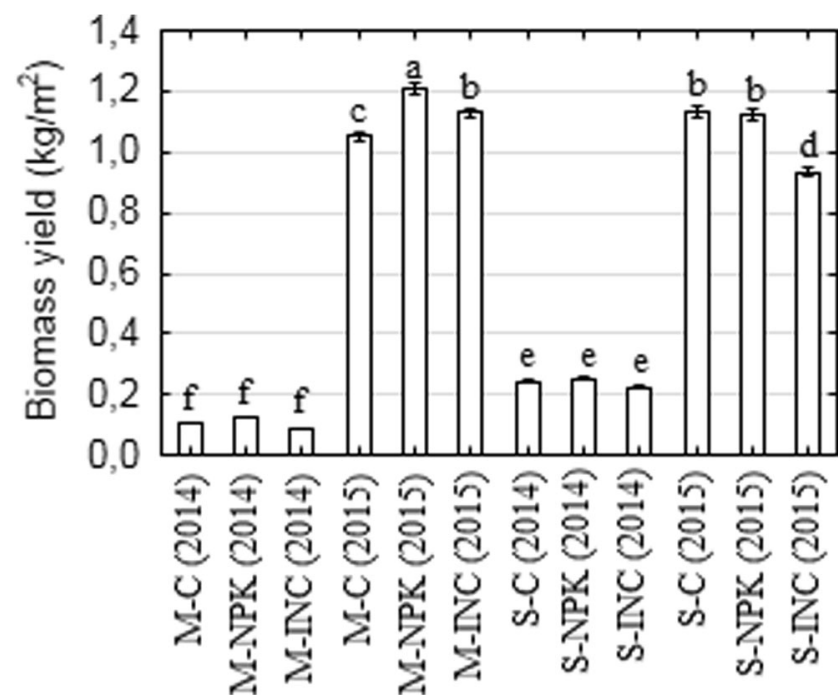

Fig. 5 Biomass yield of Miscanthus x giganteus and Spartina pectinata after 2014 and 2015 growing seasons Data are means $\pm \operatorname{SE}(n=5)$. A lower case letter (a, b, c, d, e, f) denotes significant differences among biomass yield obtained from different plots at $P \leq 0.05$ according to the Fisher LSD test. $M$ Miscanthus x giganteus, $S$ Spartina pectinata, $C$ control, NPK NPK fertilizer, INC microbial inoculum

concentrations of HMs on plots where $M . \mathrm{x}$ giganteus was cultivated. Those findings could be additionally supported by the fact that younger plants grown on soil contaminated with HMs are more sensitive to stress associated with an excess level of these metals than older plants, which could resulted in a lower M. x giganteus yield when compared to S. pectinata (Kocoń and Jurga 2017).

Interestingly, it was found that only $M . \mathrm{x}$ giganteus showed a positive response in biomass yield to the applied fertilizers. Contrary results were obtained for $S$. pectinata, confirmed by a similar yield obtained after NPK chemical fertilization and lower yield after microbial inoculation when compared to control. Monti and Zegada-Lizarazu (2016) reported that during 16 years of Arundo donax L. cultivation supplemented with a moderate dose of $\mathrm{N}$ fertilizer, no significant effect on the obtained biomass yield was observed. Application of a

Table 3 Results of three-way ANOVA testing the effects of plant $(\mathrm{P})$, year $(\mathrm{Y})$, and fertilization $(\mathrm{F})$ and combine effects of those factors on different biomass composition parameters

\begin{tabular}{|c|c|c|c|c|c|c|c|c|c|}
\hline \multirow[t]{2}{*}{ Factor } & \multicolumn{9}{|l|}{$F$ value } \\
\hline & Water content & $\mathrm{Mg}$ & $\mathrm{Ca}$ & $\mathrm{N}$ & $\mathrm{P}$ & $\mathrm{K}$ & $\mathrm{Pb}$ & $\mathrm{Cd}$ & $\mathrm{Zn}$ \\
\hline Plant & $145.27 * * *$ & $195.43 * * *$ & $25.02 * * *$ & $53.32 * * *$ & $18.21 * * *$ & $34.95 * * *$ & $11.56^{* *}$ & $183.54 * * *$ & $139.41 * * *$ \\
\hline Year & $554.99 * * *$ & $12.08 * *$ & $29.60 * * *$ & $376.22 * * *$ & $241.09 * * *$ & $102.95 * * *$ & $55.57 * *$ & $12.64 * * *$ & $114.22 * * *$ \\
\hline Fertilization & 0.19 & $8.05 * * *$ & 0.45 & 0.75 & 0.88 & 2.28 & 3.09 & 2.51 & $3.52 *$ \\
\hline $\mathrm{P} \times \mathrm{Y}$ & 1.01 & $31.04 * * *$ & 2.18 & $34.70 * * *$ & $5.47 *$ & $5.54^{*}$ & $15.56 * *$ & $18.52 * * *$ & $35.91 * * *$ \\
\hline $\mathrm{P} \times \mathrm{F}$ & 0.52 & $6.75 * *$ & 0.17 & 2.37 & 0.42 & $6.70^{* *}$ & 1.03 & 1.07 & $10.51 * * *$ \\
\hline $\mathrm{Y} \times \mathrm{F}$ & 0.56 & 2.355 & $4.34^{*}$ & 2.04 & $5.36^{* *}$ & 0.16 & 1.30 & 1.27 & 0.60 \\
\hline$P \times Y \times F$ & 0.64 & 0.566 & 1.32 & $4.82 *$ & 2.39 & 1.51 & $8.30 * * *$ & 0.99 & $4.51^{*}$ \\
\hline
\end{tabular}

$* P<0.05, * * P<0.01, * * * P<0.001 ;$ significant values $(P<0.05)$ 
higher dose of $\mathrm{N}$ fertilizer resulted in a significantly higher biomass yield only in a few growing seasons. This phenomenon reported by Monti and Zegada-Lizarazu could indicate that the response of grasses to fertilization depended not only on the dose of the fertilizer but the growing season as well. A lower biomass yield obtained for inoculum-treated $S$. pectinata plant may imply competition between indigenous microorganisms and those present in inoculant were taken into consideration. Vázquez et al. (2000) reported that after inoculation, modifications of the microbial community structure and ecology were found; however, the quality and quantity of these modifications could be unexpected especially for plant growth and development.

Despite the fact that the described experiment was not carried out additionally on an uncontaminated soil, the application of fertilizers resulted in a changed pattern of the spider charts. Interestingly, while a spider chart pattern covered a larger area conditioned by primary macronutrients simultaneously, the smaller area conditioned by HMs was covered. The results seem to confirm our hypothesis, that HMs can decrease primary mineral macronutrients in plants. Patterns of reducing primary macronutrients due to the increase of HMs are visible for $M$. x giganteus as well as for $S$. pectinata in both analyzed growing seasons. In this case for both plants species in the HMs spider charts area, $\mathrm{Zn}$ seemed to be the dominating factor in conditioning the area size within the first growing season, which was also revealed by three-way ANOVA, while $\mathrm{Pb}$ seemed to condition the second season. There are reports which indicate HMs influence on mineral macronutrients accumulation in different plant species (Goncalves et al. 2009; Naz et al. 2013); however, there are also reports which show no effect of HMs on plant mineral macronutrients composition (Zhang et al. 2002; GaredeaTorresdey et al. 2004). This influence is dependent on the plant species, cultivar, concentration of HMs in soil (medium), time of exposure, and the environment or medium in which plants were cultivated (Zhang et al. 2002; Goncalves et al. 2009). Additionally, there is shortage of papers showing the influence of HMs on primary mineral macronutrients in S. pectinata (Helios et al. 2014) and M. x giganteus (Nsanganwimana et al. 2016).

The general spider chart pattern overview indicated that $M$. $\mathrm{x}$ giganteus demonstrated a better ability to accumulate heavy metals, as well as mineral macronutrients. In fact, in the initial soil, higher values for those elements on $M$. x giganteus plots were observed, which undeniably influenced their accumulation in plants. After the second growing season, the differences in the overall accumulation between species were not as high as in the first one. Korzeniowska and StanislawskaGlubiak (2015) reported that in the microplot experiments with artificially contaminated soil up to the depth of 0 $30 \mathrm{~cm}, S$. pectinata had a better ability to accumulate $\mathrm{Zn}$ in aboveground organs in the second year after the experiment establishment than $M$. x giganteus. Although an opposite phenomenon was observed in our research, differences could be explained by the lack of soil homogeneity when considering differences between plant species.

Lead concentration presented on the spider charts and the PCA analysis, after the second growing season, showed inconsistent patterns throughout the year. An increased $\mathrm{Pb}$ concentration was observed for $S$. pectinata while for $M$. x giganteus it remained unchanged, with the exception of NPK-treated plants, where it was increased. Lead accumulation in aerial parts depended mainly on the age of the leaves. It has been found that the highest concentration of $\mathrm{Pb}$ occurred in the senescing leaves while the lowest was observed in the young ones (Islam et al. 2008). This can be associated with $\mathrm{Pb}$ 's ability to form complexes with anionic sites associated with pectic substances within the cell wall (Donnan-free space) (Singh et al. 1997). Such a phenomenon corresponds with the obtained results, where the relocation of $\mathrm{Pb}$ was limited and stayed on the same level, regardless to the progression of senescence each year.

$M$. x giganteus and S. pectinata biomass can be processed in many ways depending on the stage of the plants growth and the availability of the processing technologies. There are many reports which describe different approaches to energy production from biomass produced from these plants. Most of the technologies are connected with biomass thermo-chemical conversion (McKendry et al. 2002a) and typically require dry biomass (low moisture content). For that purpose, plants are usually harvested at late winter or early spring (McKendry et al. 2002b; Robson et al. 2012). However, there are also processes which prefer green (high moisture content) biomass (McKendry et al. 2002a).

In case of perennial grasses which acquire mineral nutrients to the rhizomes, plant senescence is the most important factor that determines the time of biomass harvesting. It was reported that in plants harvested at the beginning of autumn, the allocation process of elements is weaker in the following year due to interference (Kiesel and Lewandowski 2017). The senescence process is not constant for plants every year; it can be hasted or delayed by many factors including environmental (Thomas 2013; Lim et al. 2007) and plantation age in the field condition (M. Pogrzeba, personal communication). In the presented study, time varying senescence is showed on the spider charts and the PCA analysis. After the second growing season, a considerably lower concentration of the mineral macronutrients and water content was observed when compared to the first one, which could correspond to the hasted allocation of nutrients. To coop with different senescence time, which could depend on the weather conditions, there is a need of a method that would be suitable to determine the development stage of a plant. For that purpose, portable chlorophyll content meters could be used as a senescence indicator, as previously reported (Mos et al. 2013). 


\section{Conclusion}

Fertilizers application had a positive effect on $M$. x giganteus biomass yield, while NPK chemical fertilizer and microbial inoculum had no effect and caused lower yield of S. pectinata. Macronutrients concentration (particularly N and K) were affected by higher heavy metals concentration in shoots resulted from different fertilization regimes. Relocation of $\mathrm{Pb}$ was limited and stayed on the same level, regardless to the progression of senescence each year. Drought observed during the 2015 growing season caused hasted senescence when compared to the 2014 growing season.

Acknowledgements The authors wish to extend their appreciation to Mr. Henry Schelonzek and Mrs. Izabela Ratman-Kłosińska for their editorial contributions to this paper.

Funding information This work was supported by the Seventh Framework Programme of the European Union (grant number 610797) and Polish Ministry of Science and Higher Education (Institute for Ecology of Industrial Areas statutory funds).

Open Access This article is distributed under the terms of the Creative Commons Attribution 4.0 International License (http:// creativecommons.org/licenses/by/4.0/), which permits unrestricted use, distribution, and reproduction in any medium, provided you give appropriate credit to the original author(s) and the source, provide a link to the Creative Commons license, and indicate if changes were made.

\section{References}

Alloway BJ (2013) Sources of heavy metals and metalloids in soils. In Heavy metals in soils (pp. 11-50). Springer Netherlands

Balsamo RA, Kelly WJ, Satrio JA, Ruiz-Felix MN, Fetterman M, Wynn R, Hagel K (2015) Utilization of grasses for potential biofuel production and phytoremediation of heavy metal contaminated soils. Int J Phytoremediation 17:448-455. https://doi.org/10.1080/ 15226514.2014.922918

Bello MO, Ibrahim AO, Ogunwande IA, Olawore NO (2004) Heavy trace metals and macronutrients status in herbal plants of Nigeria. Food Chem 85:67-71. https://doi.org/10.1016/j.foodchem.2003.06.004

Borkowska H, Molas R (2013) Yield comparison of four lignocellulosic perennial energy crop species. Biomass Bioenergy 51:145-153. https://doi.org/10.1016/j.biombioe.2013.01.017

Bremner JM (1996) Nitrogen - total. In: Sparks DL, Page AL, Helmke PA, Loeppert RH, Soltanpour PN, Tabatabai MA, Johnston CT, Sumner ME (eds) Methods of soil analysis, part 3: chemical method. American Society of Agronomy and Soil Science Society of America, Madison, pp 1085-1121

Dz.U (2016) poz. 1395. Decision of the Polish Ministry of Environment on the soil quality standards and assessment of soil contamination

Egnér H, Riehm H, Domingo WR (1960) Untersuchungen über die chemische Bodenanalyse als Grundlage für die Beurteilung des Nährstoffzustandes der Böden. II. Chemische Extraktionsmethoden zur Phosphor-und Kaliumbestimmung. Kungliga Lantbrukshögskolans Annaler 26:199-215

Gardea-Torresdey JL, Peralta-Videa JR, Montes M, De la Rosa G, CorralDiaz B (2004) Bioaccumulation of cadmium, chromium and copper by Convolvulus arvensis L.: impact on plant growth and uptake of nutritional elements. Bioresour Technol 92:229-235. https://doi.org/ 10.1016/j.biortech.2003.10.002

Gonçalves JF, Antes FG, Maldaner J, Pereira LB, Tabaldi LA, Rauber R, Rossato LV, Bisognin DA, Dressler VL, de Moraes Flores EM, Nicoloso FT (2009) Cadmium and mineral nutrient accumulation in potato plantlets grown under cadmium stress in two different experimental culture conditions. Plant Physiol Biochem 47:814 821. https://doi.org/10.1016/j.plaphy.2009.04.002

Helios W, Kozak M, Malarz W, Kotecki A (2014) Effect of sewage sludge application on the growth, yield and chemical composition of prairie cordgrass (Spartina pectinata link.) J Elem 4:1021-1036. https://doi.org/10.5601/jelem.2014.19.3.725

Islam E, Liu D, Li T, Yang X, Jin X, Mahmood Q, Tian S, Li J (2008) Effect of $\mathrm{Pb}$ toxicity on leaf growth, physiology and ultrastructure in the two ecotypes of Elsholtzia argyi. J Hazard Mater 154:914-926. https://doi.org/10.1016/j.jhazmat.2007.10.121

ISO 11466 (1995) - Soil quality - Extraction of trace elements soluble in aqua regia

ISO 13878 (1998) - Soil quality-determination of total nitrogen content by dry combustion ("elemental analysis")

Khan N, Bano A (2016) Role of plant growth promoting rhizobacteria and Ag-nano particle in the bioremediation of heavy metals and maize growth under municipal wastewater irrigation. Int $\mathrm{J}$ Phytoremediation 18:211-221. https://doi.org/10.1080/15226514. 2015.1064352

Kiesel A, Lewandowski I (2017) Miscanthus as biogas substrate-cutting tolerance and potential for anaerobic digestion. GCB Bioenergy 9: 153-167. https://doi.org/10.1111/gcbb.12330

Kocoń A, Jurga B (2017) The evaluation of growth and phytoextraction potential of Miscanthus x giganteus and Sida hermaphrodita on soil contaminated simultaneously with $\mathrm{Cd}, \mathrm{Cu}, \mathrm{Ni}, \mathrm{Pb}$, and $\mathrm{Zn}$. Environ $\mathrm{Sci}$ Poll Res 24:4990-5000. https://doi.org/10.1007/s11356-016-8241-5

Korzeniowska J, Stanislawska-Glubiak E (2015) Phytoremediation potential of Miscanthus $\times$ giganteus and Spartina pectinata in soil contaminated with heavy metals. Environ Sci Pollut Res 22: 11648-11657. https://doi.org/10.1007/s11356-015-4439-1

Lewandowski I, Scurlock JM, Lindvall E, Christou M (2003) The development and current status of perennial rhizomatous grasses as energy crops in the US and Europe. Biomass Bioenergy 25:335-361. https://doi.org/10.1016/S0961-9534(03)00030-8

Lim PO, Kim HJ, Gil Nam H (2007) Leaf senescence. Annu Rev Plant Biol 58:115-136. https://doi.org/10.1146/annurev.arplant.57. 032905.105316

McKendry P (2002a) Energy production from biomass (part 1): overview of biomass. Bioresour Technol 83:37-46. https://doi.org/10.1016/ S0960-8524(01)00118-3

McKendry P (2002b) Energy production from biomass (part 2): conversion technologies. Bioresour Technol 83:47-54. https://doi.org/10. 1016/S0960-8524(01)00119-5

Meers E, Van Slycken S, Adriaensen K, Ruttens A, Vangronsveld J, Du Laing G, Witters N, Thewys T, Tack FMG (2010) The use of bioenergy crops (Zea mays) for 'phytoattenuation' of heavy metals on moderately contaminated soils: a field experiment. Chemosphere 78:35-41. https://doi.org/10.1016/j.chemosphere.2009.08.015

Monti A, Zegada-Lizarazu W (2016) Sixteen-year biomass yield and soil carbon storage of giant reed (Arundo donax L.) grown under variable nitrogen fertilization rates. Bioenergy Res 9:248-256. https:// doi.org/10.1007/s12155-015-9685-Z

Mos M, Banks SW, Nowakowski DJ, Robson PRH, Bridgwater AV, Donnison IS (2013) Impact of Miscanthus x giganteus senescence times on fast pyrolysis bio-oil quality. Bioresour Technol 129:335342. https://doi.org/10.1016/j.biortech.2012.11.069

Naz A, Khan S, Qasim M, Khalid S, Muhammad S, Tariq M (2013) Metals toxicity and its bioaccumulation in purslane seedlings grown in controlled environment. Natural Sci 5:573-579. https://doi.org/ 10.4236/ns.2013.55073 
Nazar R, Iqbal N, Masood A, Khan MIR, Syeed S, Khan NA (2012) Cadmium toxicity in plants and role of mineral nutrients in its alleviation. American J Plant Sci 3:1476-1489. https://doi.org/10.4236/ ajps.2012.310178

Nsanganwimana F, Waterlot C, Louvel B, Pourrut B, Douay F (2016) Metal, nutrient and biomass accumulation during the growing cycle of Miscanthus established on metal contaminated soils. J Plant Nutr Soil Sci 179:257-269. https://doi.org/10.1002/jpln.201500163

PN EN 14582 (2017) Characterization of waste - halogen and sulfur content - oxygen combustion in closed systems and determination method

PN ISO 14235 (2003) Soil quality - determination of organic carbon content by oxidation with dichromate (VI) in a sulfuric acid (VI) environment

PN-ISO 11265 (1997) Soil quality —electrical conductance assessment

PNR 04032 (1998)- Soils and mineral soil materials - soil sampling and determination of particle size distribution in mineral soil material

Pogrzeba M, Krzyżak J, Sas-Nowosielska A (2010). How to grow energy crop on heavy metal contaminated soil. In Proceedings of 15th International Conference on Heavy Metals in the Environment pp. 676-679

Pogrzeba M, Rusinowski S, Sitko K, Krzyżak J, Skalska A, Małkowski E, Ciszek D, Werle S, McCalmont JP, Mos M, Kalaji HM (2017) Relationships between soil parameters and physiological status of Miscanthus x giganteus cultivated on soil contaminated with trace elements under NPK fertilisation vs. microbial inoculation. Environ Pollut 225:163-174. https://doi.org/10.1016/j.envpol.2017.03.058

Robson P, Mos M, Clifton-Brown J, Donnison I (2012) Phenotypic variation in senescence in Miscanthus: towards optimising biomass quality and quantity. Bioenerg Res 5:95-105. https://doi.org/10. 1007/s12155-011-9118-6

Sarath G, Baird LM, Mitchell RB (2014) Senescence, dormancy and tillering in perennial C4 grasses. Plant Sci 217:140-151. https:// doi.org/10.1016/j.plantsci.2013.12.012

Schierup H, Larsen V (1981) Macrophyte cycling of zinc, copper, lead and cadmium in the littoral zone of a polluted and a non-polluted lake. I. Availability, uptake and translocation of heavy metals in Phragmites australis (Cav.) Trin. Aquat Bot 11:197-210. https:// doi.org/10.1016/0304-3770(81)90061-9

Siedlecka A (2014) Some aspects of interactions between heavy metals and plant mineral nutrients. Acta Soc Bot Pol 64:265-272. https:// doi.org/10.5586/asbp.1995.035
Singh B, Dang YP, Mehta SC (1990) Influence of nitrogen on the behaviour of nickel in wheat. Plant Soil 127:213-218. https://doi.org/10. 1007/BF00014428

Singh RP, Tripathi RD, Sinha SK, Maheshwari R, Srivastava HS (1997) Response of higher plants to lead contaminated environment. Chemosphere 34:2467-2493. https://doi.org/10.1016/S00456535(97)00087-8

Thomas H (2013) Senescence, ageing and death of the whole plant. New Phytol 197:696-711. https://doi.org/10.1111/nph.12047

Tripathi DK, Singh VP, Chauhan DK, Prasad SM, Dubey NK (2014) Role of macronutrients in plant growth and acclimation: recent advances and future prospective. In: Ahmad P, Wani MR, Azooz MM, L-SP T (eds) Improvement of crops in the era of climatic changes. Springer, New York, pp 197-216

Van Ginneken L, Meers E, Guisson R, Ruttens A, Elst K, Tack FMG, Vangronsveld J, Diels L, Dejonghe W (2007) Phytoremediation for heavy metal contaminated soils combined with bioenergy production. J Environ Eng Landsc Manag 15:227-236. https://doi.org/10. 1080/16486897.2007.9636935

Van Slycken S, Witters N, Meers E, Peene A, Michels E, Adriaensen K, Ruttens A, Vangronsveld J, Du Laing G, Wierinck I, Van Dael M, Van Passel S, Tack FMG (2013) Safe use of metal-contaminated agricultural land by cultivation of energy maize (Zea mays). Environ Pollut 178:375-380. https://doi.org/10.1016/j.envpol.2013.03.032

Vázquez MM, César S, Azcón R, Barea JM (2000) Interactions between arbuscular mycorrhizal fungi and other microbial inoculants (Azospirillum, Pseudomonas, Trichoderma) and their effects on microbial population and enzyme activities in the rhizosphere of maize plants. Appl Soil Ecol 15:261-272. https://doi.org/10.1016/S09291393(00)00075-5

Waraich EA, Ahmad R, Ashraf MY (2011) Role of mineral nutrition in alleviation of drought stress in plants. Aust J Crop Sci 5:764-777

Zhang G, Fukami M, Sekimoto H (2002) Influence of cadmium on mineral concentrations and yield components in wheat genotypes differing in Cd tolerance at seedling stage. Field Crop Res 77:93-98. https://doi.org/10.1016/S0378-4290(02)00061-8

Zhang C, Guo J, Lee DK, Anderson E, Huang H (2015) Growth responses and accumulation of cadmium in switchgrass (Panicum virgatum L.) and prairie cordgrass (Spartina pectinata Link). RSC Adv 5:83700-83706. https://doi.org/10.1039/C5RA13073E 